IAN HALL

\title{
India's New Public Diplomacy
}

\section{Soft Power and the Limits of Government Action}

\begin{abstract}
Over the past decade, India has invested significant resources in public diplomacy, using traditional and new approaches to build and leverage its soft power. This article examines the reasons for this investment, the various forms of public diplomacy India employs, and the effectiveness of its efforts to shape public opinion. It finds that Indian investment in public diplomacy is partly a response to concerns about the perceived growth of Chinese soft power and partly a function of changed beliefs in the foreign policy-making elite about the uses of new social media. It also finds that India's new public diplomacy seems to have met with some-albeit patchy—success in augmenting its soft power.
\end{abstract}

KEYWORDS: India, public diplomacy, soft power, foreign policy, social media

On July 8, 20io, India's Ministry of External Affairs (MEA) sent its first "tweet." This use of the popular social media tool was just one of a series of efforts to bolster and leverage India's soft power by improving its public diplomacy by engaging with Web 2.0. ${ }^{2}$ Since then the MEA has inaugurated a new web portal for Indian Public Diplomacy; released a string of videos on YouTube and a portfolio of photographs on Flickr; launched a dedicated Facebook page; and, in conjunction with the Center for Media

IAN HALL is Senior Fellow in the Department of International Relations, Australian National University, Canberra. He is grateful to Renée Jeffery, Frank Smith, and two anonymous reviewers for their comments on and criticisms of this article. Email: <ian.hall@anu.edu.au>.

I. The MEA Twitter account is called @IndianDiplomacy. The first tweet announced the publication of a new issue of the MEA's journal, Indian Perspectives. By early October 20I2, the MEA had sent 2,477 tweets and had 43,5I2 followers.

2. The concept of "soft power" was first developed by Joseph S. Nye (see especially Soft Power: The Means to Success in World Politics [New York: Public Affairs, 2007]). For Nye, soft power is the product not just of government action, which he thinks can "reinforce or squander" this "power of attraction," but of a society's culture and values, as well as economic and intellectual successes (p. I4). For a critical assessment, see Steven R. Rothman, "Revising the Soft Power Concept: What Are the Means and Mechanisms of Soft Power?" Journal of Political Power 4:I (20II), pp. 49-64.

Asian Survey, Vol. 52, Number 6, pp. I089-IIIo. ISSN o004-4687, electronic ISSN 1533-838X. (C) 2012 by the Regents of the University of California. All rights reserved. Please direct all requests for permission to photocopy or reproduce article content through the University of California Press's Rights and Permissions website, http://www.ucpressjournals.com/reprintInfo.asp. DOI: AS.20I2.52.6.Io89. 
Studies Academy in New Delhi, held its first conference on the theory and practice of public diplomacy. ${ }^{3}$ These ventures follow close on the heels of three other significant recent initiatives: a dedicated Public Diplomacy Division within the MEA in May 2006, a raft of new schemes designed to engage domestic and foreign public opinion, and a series of high-profile dialogues with foreign think tanks, most notably with the London-based International Institute for Strategic Studies (IISS). ${ }^{4}$

These various developments are eye-catching, but they are not without precedent. India has a long history of trying to use public diplomacy and other instruments of soft power to secure its foreign policy objectives. ${ }^{5}$ After Independence, India invested considerable resources in high-level dialogues, intellectual and cultural exchanges, and conferences of concerned parties, seeking to influence peoples as well as governments by using open diplomacy and moral suasion. To a degree, India's new public diplomacy builds upon this tradition, but it also departs from Indias past practice in three key ways. First, India’s new public diplomacy is actively seeking new audiences within India (notably, politically engaged young people at home), in the West (Indian diaspora communities abroad), and in the developing world (key opinion formers in India's immediate region or resource-rich states in the global South). Second, Indian officials are attempting to render India's foreign policy-making process more open and democratic by engaging in dialogue with communities outside the New Delhi political and diplomatic elite. Third, the effort seeks to utilize new media rather than traditional methods to reach its various target audiences.

This article examines the reasons why Indian policy makers have invested in this new public diplomacy and analyzes the prospects for its success. The first part sets out the evolving parameters of the international environment

3. The web portal is <http://www.indiandiplomacy.in> and includes links to videos of an MEAsponsored lecture series, documentary films, and Indian Perspectives, as well as details of Indian development projects in its immediate region and in Africa. It also includes an online discussion forum. The "Public Diplomacy in the Information Age" conference, held December IO-II, 20IO, has its own website, <http://publicdiplomacy20Io.in/>, accessed May 20, 20II.

4. Three dialogues with IISS have been held, in February and December 2007 and February 2010. Proceedings of the second were published in Amit Dasgupta, ed., The Strategic Shape of the World (New Delhi: Sage, 2008). Details of the first and third dialogues are available at <http://www. iiss.org/programmes/south-asia/conferences-and-seminars/iiss-mea-foreign-policy-dialogue/first-iissmea-foreign-policy-dialogue/> and <http://www.iiss.org/programmes/south-asia/conferences-andseminars/iiss-mea-foreign-policy-dialogue/third-iiss-mea-dialogue/>, accessed May 20, 201 .

5. Jacques E. C. Hymans, "India’s Soft Power and Vulnerability," India Review 8:3 (2009), pp. 234-65. 
in which India is operating, where Asian states (especially China) are increasingly devoting significant resources to public diplomacy. The second section describes the traditional mechanisms by which India has tried to project its soft power: cultural and academic exchanges, intellectual dialogue, international radio broadcasts, and sports events. The third part explores the new means that India has put in place over the past decade to bolster its public diplomacy effort. This has occurred in five particular areas: wooing diaspora communities, engaging foreign business communities, leveraging India’s nascent foreign aid programs, "branding" the Indian nation for global elites, and investing in online social networking technologies.

This article argues that India's new public diplomacy is in part a response to recent efforts by other Asian states—especially China—-to build and leverage soft power. The initiative also stems partly from a realization that India's reputation in its "near abroad" region is not as good as it might be, and it partly reflects a new elite enthusiasm for technologically driven solutions to political challenges. ${ }^{6}$ India is investing in technology because it does not want to be left behind in the "arms race" for soft power and because some policy makers genuinely believe that social media, in particular, are transforming the practice of politics. The problem, however, is that the existing evidence about the effectiveness of public diplomacy in general, and new public diplomacy in particular, is mixed.

\section{THE RISE OF PUBLIC DIPLOMACY IN ASIA}

Over the past decade, Asian states have become increasingly interested in public diplomacy as a means by which they can try to influence foreign public opinion. ${ }^{7}$ Governments use public diplomacy to help foster favorable views of their policies among foreign publics and thereby more easily achieve their foreign policy objectives. Public diplomacy is about "changing minds." It can consist of simple propaganda, but it is arguably more successful if it aims at building

6. The ambitious plan to provide biometric identity cards to all Indian citizens, as well as the unusual strategy used to ensure the efficient delivery of the cards by contractors, is another example of this tendency. See "Identifying a Billion Indians," The Economist, January 27, 20II, at <http:// www.economist.com/node/I80I0459>, accessed May 20, 2011.

7. See Ian Hall and Frank Smith, "The Struggle for Soft Power in Asia: Public Diplomacy and Regional Competition," Asian Security 9:I (2013), forthcoming.

8. Edward P. Djerejian, Changing Minds, Winning Peace: A New Strategic Direction for U.S. Public Diplomacy in the Arab and Muslim World (West Bethesda, Md.: Crossbow Press, 2007). 
lasting relationships of trust between a government and foreign audiences. ${ }^{9}$ Practitioners of public diplomacy use an array of different means to build these relationships. They can use government-funded media outlets, ranging from state-directed/controlled TV or radio stations to state-sponsored but editorially independent media like the British Broadcasting Corporation's (BBC) World Service. They can utilize cultural and educational exchanges, which aim to educate as well as entertain foreign audiences or to generate lasting relationships between individuals or groups. The practitioners also use advertising in traditional or new media, branding, and other forms of public relations or strategic communications. The object of these efforts is to gain influence, but not necessarily in the short term or for a particular policy. Rather, public diplomacy often aims at building longer-lasting networks of individuals and institutions that may influence the wider relationship between states and peoples. Indeed, these long-term networks are commonly argued to be its primary goal.

Public diplomacy therefore aims to build and leverage the soft power of societies for the benefit of the state. "Soft power," as defined by the scholar who coined the term, Joseph S. Nye, is the power that societies have to attract others to support the policies pursued by their governments. ${ }^{10}$ Unlike hard power, which is wielded to coerce others, soft power consists of those aspects of a society-its literature or movies, fashions or food-that appeal to others and make them better disposed toward that society. It can also be located in less tangible national assets-in the reputation of an institution for honesty or trustworthiness (e.g., the BBC World Service)—or in the perception that a society's political system is open, fair, and untainted by corruption. The attractiveness of these soft power assets to foreign audiences is useful to governments, but leveraging the assets effectively for diplomatic gain can be difficult. Some observers doubt whether government-directed public diplomacy can affect a society's soft power in any substantive way and whether such efforts can significantly influence foreign public opinion. As the U.S. example demonstrates clearly, a state whose society possesses great reserves of soft power can still struggle to make them work in support of that state's foreign policy. ${ }^{11}$

9. See Mark Leonard, Public Diplomacy (London: Foreign Policy Centre, 2002).

Io. See Nye, Soft Power.

II. Carnes Lord, Losing Hearts and Minds? Public Diplomacy and Strategic Influence in the Age of Terror (Westport, Conn.: Praeger, 2006). See also Hall and Smith, "The Struggle for Soft Power in Asia." 
Public diplomacy played a prominent role in the Cold War and was widely practiced by both the U.S. and Soviet Union, ${ }^{12}$ but it has come to the fore in Asia only in the past Io years. The People's Republic of China (PRC) has been the regional pioneer, forging a coherent and well-funded public diplomacy strategy over the past decade. In the first phase, from 2000 to 2004, China began by improving its hitherto difficult relations with the international media and by investing in state-run media services designed for foreign consumption. In the second, from 2004 to 2008 , it used these channels to deploy a consistent media narrative about China's "peaceful rise" (heping jueqi) while building up the institutional architecture needed to develop and leverage its soft power over the longer term. To that end, China established a new Public Diplomacy Division in the Information Department of the Ministry of Foreign Affairs and opened the first of a numerous Confucius Institutes, based on the established models of the British Council and Maison Française. ${ }^{13}$ In the most recent phase, China has made extensive use of set-piece events to showcase its development and cultural values, most obviously at the Beijing Olympics in 2008 and again at Expo 2oro Shanghai. At the same time, China has also begun to publicize far more prominently its aid, development, and disaster-relief efforts in its immediate region and in Africa. ${ }^{14}$

Whether this considerable Chinese investment in public diplomacy, estimated at almost US\$9 billion in $2009-\mathrm{IO},{ }^{15}$ has actually paid dividends is a matter of dispute. It has certainly not stanched the flow of words on the "China threat"; indeed, in some ways China's "charm offensive" has

I2. Nicholas J. Cull, The Cold War and the United States Information Agency: American Propaganda and Public Diplomacy, 1945-1989 (Cambridge: Cambridge University Press, 2010); and Roderic Lyne, "Making Waves: Mr Gorbachev's Public Diplomacy, I985-86," International Affairs 63:2 (1987), pp. 205-24.

I3. Yiwei Wang, "Public Diplomacy and the Rise of Chinese Soft Power," Annals of the American Academy of Political and Social Science 6I6 (2008), p. 260. The English language service of China's CCTV was created in 1986, but only began broadcasting to foreign audiences in 1993. Its 24-hour news channel was founded in 2000, with French and Spanish versions launched in 2004. The website of the PRC Foreign Ministry Information Department is at <http://www.mfa.gov.cn/eng/wjb/zzjg/ xws/>, accessed May 20, 20II. The Office of Chinese Language Council International (Hanban) aimed to have 500 Confucius Institutes open in foreign universities worldwide by the end of 2010 and $\mathrm{I}, 000$ by 2020 . The institutes provide Chinese language teaching and cultural activities.

I4. Gary D. Rawnsley, "China Talks Back: Public Diplomacy and Soft Power for the Chinese Century," in Nancy Snow and Philip M. Taylor, eds., Routledge Handbook of Public Diplomacy (New York: Routledge, 2009), pp. 283-84.

I5. Shafi Rahman, "Slouching Tiger, Racing Dragon," India Today, July 3, 2010, at <http:// indiatoday.intoday.in/site/story/slouching-tiger,-racing-dragon/I/IO394I.html>, accessed May 20, 20 II. 
increased suspicion of its intentions in the region and more widely. ${ }^{16}$ The China example has also prompted other Asian states to bolster their own public diplomacy efforts, some of which may eventually undermine China's campaign. ${ }^{17}$ Since China began to try to improve its image, Japan (2004), Malaysia (2006), and India (2006) have established public diplomacy divisions within their foreign ministries. South Korea has moved to expand the number of its Sejong Hakdang (King Sejong) Institutes for Korean studies and language from some 35 centers, mainly in Europe and North America, to I50 worldwide by $2015 .{ }^{18}$ Japan has also begun to redevelop its overseas language and cultural centers under the auspices of the Japan Foundation and to revamp its student and cultural exchange programs through the Foundation's new Center for Global Partnerships. ${ }^{19}$ Indonesia, which established its Directorate of Public Diplomacy (now the Directorate-General of Information and Public Diplomacy) in 2002 in response to 9/II, runs a number of prominent initiatives including the annual Asia-Europe Meeting's (ASEM) Interfaith Dialogue, first held in Bali in 2005.

Throughout Asia, public diplomacy efforts have been accelerated in the old and new media. Japan public broadcaster NHK now runs a substantive Web-based news service in I8 languages, from Arabic to Vietnamese, which includes downloadable video clips and podcasts. ${ }^{20}$ Japan has also recently been exploring the possibilities of using its anime and manga cartoons to engage overseas audiences with Japanese culture, awarding prizes to foreign filmmakers and artists who produce material in the genres. ${ }^{21}$ Singapore, for its part, has established a long-term strategy to brand itself as a creative economic

I6. Renée Jeffery, "Evaluating the 'China Threat': Power Transition Theory, the Successor-State Image, and the Dangers of Historical Analogies," Australian Journal of International Affairs 63:2 (2009), pp. 309-24; Joshua Kurlantzick, Charm Offensive: How China's Soft Power Is Transforming the World (New Haven, Conn.: Yale University Press, 2007).

I7. Yee-Kuang Heng, "Mirror, Mirror on the Wall, Who Is the Softest of Them All? Evaluating Japanese and Chinese Strategies in the 'Soft' Power Competition Era," International Relations of the Asia-Pacific Io (2010), pp. 275-304.

I8. The Sejong Hakdang website is available at <http://eng.sejonghakdang.org/front.jsp>, accessed May 20, 201 .

I9. Tadashi Ogawa, "Origin and Development of Japan's Public Diplomacy," in Snow and Taylor, ed., Routledge Handbook of Public Diplomacy (New York: Routledge, 2009), pp. 270-8I.

20. For the English language service, see <http://www.nhk.or.jp/nhkworld/index.html>, accessed May 20, 20II.

2I. See, for example, a speech by former Foreign Minister Aso Taro, "A New Look at Cultural Diplomacy: A Call to Japan's Cultural Practitioners," April 28, 2006, at <http://www.mofa.go.jp/ announce/fm/aso/speecho6o4-2.html>, accessed May 20, 201 . 
and cultural center, utilizing interactive websites as well as social networking sites like Facebook. ${ }^{22}$

These efforts are not confined to the more-developed Asian states. In 20IO, even Myanmar launched an international TV service, MRTV-3, with a companion website in English and Korean; it hosts a colorful official website and is reported to have begun posting video clips on YouTube and messages on Twitter. ${ }^{23}$ Asian public diplomacy may well be "still in its infancy," as Simon Anholt has suggested, but it is growing up fast. ${ }^{24}$

\section{INDIA REACTS}

In the Indian case, as elsewhere in Asia, the rise of China is one of the major reasons for the rush to build capacity in public diplomacy. The Chinese "charm offensive" has generated considerable anxiety in India and prompted calls for a similar effort by New Delhi and by concerned outsiders. A number of Indian and foreign observers have argued that despite India's having a better "brand" than China—thanks largely to the former's democratic politics, Bollywood movies, and information technology (IT) industry-Indian diplomats have done too little in the past to press home that advantage, leaving the field to the better funded, better organized Chinese. ${ }^{25}$ Although such analyses rarely cite any substantive evidence that Chinese public diplomacy is working as intended - and, as we shall see, there are reasons to think otherwise- their authors insist India should do more just in case China's approach is working. In this sense, India's new public diplomacy is part of

22. See <http://app.www.sg/>_- "Your Official Guide to Singapore" — and its fan-page on Facebook at <http://www.facebook.com/www.sg>, both accessed May 20, $201 \mathrm{I}$.

23. For Myanmar's TV station, see <http://www.mrtv3.net.mm/>; and for the DPRK's official website, see <http://www.korea-dpr.com/>, both accessed May 20, 20II. See also Rick Wallace, "N Korea Propaganda Enters YouTube Age," The Australian, August I2, 20IO, at <http://www.theaustralian.com.au/news/world/n-korea-propaganda-enters-youtube-age/story-e6frg6so-I225904IooII9>, accessed May 20, 20II.

24. Simon Anholt, "Nation-Branding in Asia," Place Branding and Public Diplomacy 4 (2008), pp. $265-69$.

25. Rahman, "Slouching Tiger, Racing Dragon"; John Lee, "Hardsell Soft Power," Hindustan Times, July 2, 20IO, at <http://www.cis.org.au/media-information/opinion-pieces/article/I733-hardsell-soft-power>; and Philip Seib, "India Is Looking Anew at Its Public Diplomacy," The CPD Blog (USC Center for Public Diplomacy, University of Southern California), <http://uscpublicdiplomacy. org/index.php/newswire/cpdblog_detail/india_is_looking_anew_at_its_public_diplomacy/>, both accessed May 20, 20II. 
a wider policy of strategic "hedging" in response to China's rise, involving emulation, balancing, and engagement. ${ }^{26}$

Chinese public diplomacy is not, however, the sole stimulant of Indian efforts. Three other factors have been at play. The first is the perception within the Indian government, including the MEA, that India's image in its immediate region is not as good as it might be. Since the early I990s, India has adopted noticeably softer lines toward Bangladesh, Nepal, Pakistan, and Sri Lanka, aiming, as one analyst put it, to be seen as less of a "regional bully" and more of a "benign hegemon." 27 Part of this new strategy involves emphasizing what a former senior official in the MEA, Rajiv Sikri, calls the "cultural unity" of South Asia. This common heritage, according to Sikri, is not just displayed in religion, cricket, and "dress, food habits, marriage, and social customs," but underpins a "common political culture" in South Asia. ${ }^{28}$ India therefore ought to utilize and build upon these cultural commonalities to counter the regional tendency to wrap "their respective national flags around an exclusivist, somewhat artificial, identity based on religion or ethnicity." ${ }^{29}$ In practice, this involves more intensive, albeit traditional, public and confidential diplomacy_- "more high-level visits, telephonic conversations and informal contacts, using pegs like private visits, religious pilgrimages and [travel stopovers] in order to make personal assessments, exchange views, [and] resolve problems." ${ }^{30}$

This kind of thinking played a role in the creation of the MEA's Public Diplomacy Division (PDD) in 2006. Externally, the PDD initially concentrated on improving India's image in its immediate region and the developing world, leaving public diplomacy directed at the West, as well as at East and Southeast Asia, largely in the hands of embassies and consulates. Under the leadership of Amit Dasgupta, joint secretary of the PDD from 2006 to 2009, a series of conferences and workshops was organized with participants from

26. See Sujit Dutta, "Managing and Engaging Rising China: India’s Evolving Posture," Washington Quarterly 34:2 (20II), pp. I27-44; and Ian Hall, "China Crisis? Indian Strategy, Political Realism, and the Chinese Challenge," Asian Security 8:I (2012), pp. 84-92.

27. Christian Wagner, "From Hard Power to Soft Power? Ideas, Interactions, Institutions, and Images in India's South Asia Policy," Heidelberg Papers in South Asian and Comparative Politics 26 (2005), pp. I2-13.

28. Rajiv Sikri, Challenge and Strategy: Rethinking India's Foreign Policy (New Delhi: Sage, 2009), p. 17.

29. Ibid., p. 22.

30. Ibid., p. 24. For an assessment of Sikri's prescriptions, see Ian Hall, "The Other Exception? India as a Rising Power," Australian Journal of International Affairs 64:5 (2010), pp. 603-13. 
Afghanistan, Ethiopia, Kazakhstan, Mauritius, Mongolia, Nepal, Pakistan, South Africa, Taiwan, and Tajikistan. The PDD also generated about 20 documentaries a year on India and its region, mainly in English and South Asian languages, including versions in Dari and Pashto for Afghan audiences, as well as books in Tamil and Nepali. ${ }^{31}$

In 2009, however, the PDD changed tack under its new head, Navdeep Suri, moving more positively into new media and Web 2.o. This shift was driven by the growing belief among some within and outside the MEA that new technologies could transform diplomacy and politics in general, and that the PDD had not yet taken full advantage of them. American influences, rather than Asian developments, were critical in shaping these convictions, which ran to a degree against traditional views in the MEA ${ }^{32}$ In particular, the PDD has drawn upon the work of the new public diplomacy by the University of Southern California (USC) Center on Public Diplomacy. For Suri, as for the USC scholars, Web 2.0 offers governments qualitatively different channels for communicating with domestic and foreign audiences in interactive (rather than unidirectional) media. More, Web 2.0 provides a means of countering negative narratives propagated by nongovernmental organizations (NGOs) or militant organizations better versed in utilizing the technology. ${ }^{33}$

Finally, the MEA's move toward the new public diplomacy is driven by the conviction that Indian foreign policy making and implementation is too insulated from the domestic public and crucial interest groups. Indeed, Indian public diplomacy is unusual in including what other governments term "public affairs" - the practice of communicating with domestic audiences — as part of its remit. One of the explanations for this tendency has been succinctly put

3I. MEA Annual Reports for 2007-08 and 2008-09, at <http://www.mea.gov.in/mystart. php?id=2702>, accessed May 20, 20II. While the PDD has recently gained more responsibility for India's public diplomacy, it is still not in a position effectively to coordinate a "whole-of-government" approach: many important elements, such as the Indian Council for Cultural Relations (ICCR) or Indian Council on World Affairs (ICWA), remain beyond its authority. See Kishan Rana, "India's Diplomatic Infrastructure and Software: Challenges for the 21st Century," Strategic Analysis 34:3 (2010), p. 367.

32. Madhavi Bhasin, "Public Diplomacy: Lessons for the Conduct of Indian Foreign Policy," Institute of Peace and Conflict Studies, Article \#2538, March 26, 2008, at <http://www.ipcs.org/ print_article-details.php? $\mathrm{recNo}=2538>$, accessed May 20, 20II. The culture-clash is highlighted in the contrasting opening remarks of Shashi Tharoor and Foreign Secretary Nirupama Rao to the Public Diplomacy Conference in New Delhi in December 20I0, at <http://www.publicdiplomacy2oro. in/>, accessed May 20, 20II.

33. Navdeep Suri, "Public Diplomacy in India’s Foreign Policy," Strategic Analysis 35:2 (201I), pp. 300-OI. 
by Shashi Tharoor: "[I]n today's world, you cannot meaningfully confine your public diplomacy to foreign publics alone. In the current media environment, whatever message any government puts out is also instantly available to its domestic audience on the internet." ${ }^{34}$

But there are additional reasons for running together public affairs with public diplomacy. One is that elements within the MEA believe that Indian foreign policy is being undermined, and especially that economic opportunities are being lost, as a consequence of the public's lack of knowledge about initiatives the central government has taken. This was the primary motivation behind the "Look East" conferences held in Guwahati, Imphal, Shillong, and Aizwal in 2007, which tried to generate dialogue between the MEA in New Delhi and important stakeholders in Indian foreign policy in the border regions, including local politicians, businesspeople, and ordinary citizens. The other is that Indian diplomats see a need to build better links with the wider foreign policy community in India, especially with universities and think tanks. This was the impetus behind the MEA Distinguished Lectures that have been delivered by diplomats and scholars at universities across India since 20I0, as well as a series of workshops and colloquia.

The new public diplomacy, in other words, is the product of several different factors. It is partly a response to Chinese efforts and to perceived Indian failings, especially in the "near abroad," and partly a function of new beliefs about the power of new technologies. As a result, tensions have arisen between the traditional and new approaches to Indian public diplomacy, with some pushing for greater investment in tried and tested practices and others advocating more involvement in social media and other novel means of communication. ${ }^{35}$ The next two sections set out these two approaches in more detail, while the conclusion evaluates the prospects for their success.

\section{THE TRADITIONAL APPROACH}

India has long sought to utilize its soft power to offset its lack of hard power and to honor the intellectual and political legacy of Mohandas Gandhi and Jawaharlal Nehru. In the I950s and I960s, in the global anti-colonial movement and in the Non-Aligned Movement that succeeded it, India sought

34. Tharoor, opening remarks to Public Diplomacy Conference 2010.

35. See Kishan Rana, The 2Ist Century Ambassador: From Plenipotentiary to Chief Executive (Vienna: DiploFoundation, 2004), pp. 84-86. 
to leverage its democratic credentials, its extraordinary history and cultural heritage, and its contributions to anti-imperialism and non-violence. During the early Cold War, Indian leaders took advantage of high-level international platforms to show off these assets, using the U.N. in particular as a forum to project India's messages to an international audience. ${ }^{36}$ Employing these resources, Nehru was able to promote his philosophy of international relations - non-alignment—and pursue what he perceived to be India's interests. ${ }^{37}$

At the same time, India developed its own means for projecting its soft power by building upon and adapting the British model, which divides public diplomacy into three parts: cultural and academic exchanges (administered mainly by the British Council); intellectual and research links (involving a number of government and private agencies, including the Royal Institute of International Affairs or Chatham House); and state-funded media targeted at foreign audiences (principally the BBC World Service). In addition, India has attempted to use international sports competitions for diplomatic initiatives, albeit to varying effect. These approaches are examined more closely below.

\section{Cultural and Academic Exchanges}

India possesses well-established institutions for public diplomacy in the areas of cultural and academic exchanges. The ICCR was founded soon after Independence, in 1950. It currently has 24 centers abroad as well as I4 regional offices within India, and plans to open another I4 centers in the near future in East and Southeast Asia, Europe, and Africa, including in Bangkok, Kuala Lumpur, Paris, Sáo Paulo, Tokyo, and Washington..$^{38}$ These centers perform different functions depending on their location. Some serve expatriate Indians or people of Indian heritage, while others - those located in major capitals such as London or Moscow-have broader roles. The smaller centers, for example in Kabul, opened in 2007, concentrate on promoting Indian literature, music, dance, and yoga. The larger centers, such as that in Suva, Fiji, which

36. J. N. Dixit, Makers of India's Foreign Policy: Raja Ram Mohun Roy to Yashwant Sinha (New Delhi: HarperCollins India, 2004), especially pp. 39-5I and pp. 79-97; Harish Kapur, Diplomacy of India: Then and Now (New Delhi: Manas Publications, 2002), pp. 236-42.

37. Khalid I. Babaa and Cecil V. Crabb, Jr., "Nonalignment as a Diplomatic and Ideological Credo," Annals of the American Academy of Political and Social Science 362 (1965), pp. 6-I7.

38. "ICCR's Global Presence: Foreign Cultural Centres," at <http://www.iccrindia.net/foreigncentres. html>, accessed May 20, 20II. 
has been operating since 1972, provide Hindi language lessons and maintain contacts with NGOs in the local Indian community.

\section{Intellectual and Research Links}

The ICCR also has primary responsibility for managing academic exchanges. It currently offers financial support for around 2,300 foreign students at Indian universities, 675 of whom come from Afghanistan and 500 from African states. The bulk of the remaining scholarships are targeted at South Asian countries, mainly Bangladesh, Mauritius, and Sri Lanka. ${ }^{39}$ For academic faculty, the ICCR provides 30 fellowships per year at Indian universities, as well as funding travel expenses for 20 or so "distinguished visitors" to India. It also pays for about 30 Indian scholars to occupy long- (two year) and shortterm (three to six month) chairs at overseas universities, about half of which are devoted to the teaching of Hindi and other Indian languages. The rest of these chairs are for scholars of peace studies, international relations, and Indian history. The ICCR is expanding this program, creating another 49 chairs mainly in North America, Europe, and Southeast Asia. ${ }^{40}$

The ICWA fulfills a different role. Founded in 1943 as an independent think tank, it has recently assumed a semi-official role and was recognized by an Act of Parliament in $200 \mathrm{I}$ as an "institution of national importance." ${ }^{41}$ The ICWA's main function is producing and disseminating research on foreign affairs, holding seminars, and publishing briefing papers and a major journal (India Quarterly), but it also plays a significant and growing role in outreach. Since 200 I the Council has signed memoranda of understanding with i9 other institutions, three within India and 16 beyond it, from Russia and China to Malaysia and the United Arab Emirates. The ICWA is also a member of the Council for Security Cooperation in the Asia-Pacific (CSCAP), which facilitates Track 2 dialogues between scholars and officials concerned with regional security, as well as research on issues of mutual concern. ${ }^{42}$ Most

39. "The Many Scholarship Schemes of ICCR," at <http://www.iccrindia.net/scholarshipschemes. html>, accessed May 20, 20II.

40. "ICCR Chairs in Foreign Countries," at <http://www.iccrindia.net/chairs.html>, accessed May 20, 20II.

4I. ICWA, at <http://www.icwa.in/>, accessed May 20, 201 I.

42. The CSCAP-India Committee is presently involved in projects on cybersecurity and naval cooperation. For details, see <http://www.cscap.org/index.php?page=study-groups $>$, accessed May 2O, $201 \mathrm{I}$. 
important, the ICWA offers a prestigious forum to which foreign leaders, diplomats, and other notables can be invited to speak.

\section{Media Resources}

India also has substantial and established state-run media outlets with a foreign presence. The External Services of All India Radio (AIR) broadcasts in 27 languages to more than IOO countries. Begun in 1939 as a means of countering Axis propaganda in the immediate region, especially in the tribal areas of what are now Pakistan and Afghanistan, AIR after Independence expanded its External Services to include broadcasts in Arabic, Baluchi, Burmese, Chinese, Dari, French, Indonesian, Nepali, Persian, Pashto, Russian, Sinhala, Swahili, Thai, Tibetan, and English, as well as II Indian languages. By far the most extensive services in a foreign language are in English, with over eight hours of daily broadcasts on shortwave radio to 79 countries. The rest of these broadcasts are far more restricted in scope, limited to an hour or two of broadcasting targeted to particular countries. The External Services' objectives, according to the AIR website, are to project India's "view point [sic], progress and policies along with art and culture" across Asia, Africa, Australia, and New Zealand, and to the United Kingdom. ${ }^{43}$

Taken together with the efforts of both the ICCR and ICWA, the External Services of AIR constitute a major sustained public diplomacy effort. However, India's state media presence overseas remains underdeveloped, especially compared to China's. India has no state-funded international news channel equivalent to Beijing's CNTV and no news website like that of the state-run news agency Xinhua. When it comes to cultural diplomacy, there are also clear limits to India's soft power projection capabilities. Even after the slated expansion in their numbers, ICCR cultural centers located abroad will still number fewer than 50, compared to China's 500 Confucius Institutes or the 200 offices of the British Council. While it is hard to establish a clear estimate, it appears that these centers have enrolled far fewer students in Hindi or other Indian language courses than the quarter of a million that Chinese officials claim are studying Chinese at Confucius Institutes. ${ }^{44}$ Moreover, as the next section will analyze in more detail, India's intended primary market for the

43. AIR External Services Division, at <http://www.allindiaradio.org/external.html>, accessed May 20, 20II.

44. "Confucius Institute/Classroom," at <http://english.hanban.edu.cn/node_I097I.htm>, accessed May 20, 20II. 
kinds of cultural commodities traded by the ICCR are people of Indian origin living overseas, rather than foreign nationals of non-Indian origin.

\section{Sports Diplomacy}

Lastly, India's attempts at sports diplomacy should not be overlooked, not least because there is at present a significant debate in South Asia about the links between sports, principally cricket, and politics. Athletics has long had a political dimension for Indians, especially in their relations with other nations in the subcontinent. "Cricket diplomacy" has been particularly prominent in Indo-Pakistani relations since the mid-I980s, with Test matches between the two states being arranged by one or the other to signal a readiness to negotiate or to provide a means of lowering tensions. ${ }^{45}$ Recently, however, cricket has served to exacerbate rather than diminish conflict, not least in early 20I0, when the Indian Premier League teams collectively refused to bid for Pakistani cricketers during the player auction, an act that prompted a denial of official involvement from Minister of External Affairs S. M. Krishna. ${ }^{46}$ Whether the staging of the 2010 Commonwealth Games in New Delhi enhanced or undermined India's image remains a matter of debate.

\section{THE NEW INDIAN PUBLIC DIPLOMACY}

Since 2000, India has looked beyond these well-established traditional instruments of public diplomacy and employed a number of new initiatives, some coordinated by the MEA and some by other parts of government. Five developments are especially significant: (I) India's effort to reach out to overseas Indians $;{ }^{47}$ (2) its attempts to build connections with foreign business interests; (3) its nascent foreign aid and development program; (4) its use of major events to showcase and "nation-brand" India; and ( 5$)$ its use of new social media to reach out to younger, tech-savvy audiences. All of these involve deliberate attempts to build alternative means of influencing foreign audiences to those employed by established institutions such as the

45. Emily Crick, "Contact Sport: Cricket in India-Pakistan Relations since 1999," South Asian Survey I6:I (2009), pp. 59-79.

46. Declan Walsh, "IPL's Snubbing of Pakistani Players Provokes Political Tension," The Guardian, January 2I, 20IO, at <http://www.guardian.co.uk/sport/20Io/jan/2I/ipl-india-pakistan>, accessed May 20, 20II.

47. On relations with the Indian diaspora in general, see Latha Varadarajan, The Domestic Abroad: Diasporas in International Relations (New York: Oxford University Press, 2010). 
ICCR or ICWA and the traditional media. In particular, they differ from the traditional channels in their extensive use of new media, with some material aimed at general domestic or foreign audiences and some at targeted groups.

In 2004, India established a separate Ministry of Overseas Indian Affairs (MOIA, originally called the Ministry of Non-Resident Indians' Affairs). Its mandate, according to its website, is to be "the nodal point which Overseas Indians, Diaspora associations, trade and industry, lawmakers, think-tanks and opinion builders, key stakeholders of society and governance, and state governments, turn to for information, partnerships and facilitation for all matters relating to overseas Indians." ${ }^{38}$ The ministry was designed to be agile and responsive, rather than the traditional lumbering institution, while promising to implement the kind of "joined-up" governance approach characteristic of Western European agencies. The MOIA is intended not just to serve the interests of overseas Indians but to showcase the new India to them and to others: it is meant to be "dynamic, young and interactive," as well as "contemporary, lean and efficient." ${ }^{49}$

Since 2004, the Indian federal government has made a substantial investment in the MOIA. Its budget has grown from just Rs 7 crore (\$I.6 million at June 2005 exchange rates) in 2004-05 to an estimated Rs 80 crore ( $\$ 17$ million at June 2010 rates) in 2009-10. In comparison, the Ministry of External Affairs had a budget of around Rs 630 crore (\$134.5 million), and the Ministry of Information and Broadcasting was allocated some Rs 800 crore (\$170.8 million) in 2009-10.50 The bulk of this growth in the MOIA budget has been expenditure on publicity, seminars, and conferences, including the annual Pravasi Bharatiya Divas (Day of Indians Abroad) conventions that MOIA organizes in conjunction with the municipal government of Delhi and the Confederation of Indian Industry. ${ }^{51}$ These conventions are intended to link federal and state politicians with representatives from significant

48. MOIA, "Mandate," at <http://www. moia.gov.in/services.aspx?idI $=8 \&$ idp $=8 \&$ mainid $=6>$, accessed May 20, 20II.

49. Idem, "An Overview," at <http://moia.gov.in/services.aspx?mainid=6>, accessed May 20, 2011.

50. For the MOIA budget, see <http://moia.gov.in/writereaddata/pdf/budget_grapho9-Io.pdf>; and for details of other departments' budgets, see <http://indiabudget.nic.in/ub2009-Io/bag/bag4-2. htm>, both accessed May 20, $201 \mathrm{I}$.

5I. The Pravasi Bharatiya Divas convention has been held on January 9 every year since 2003, marking the date that Gandhi returned to India in I9I5 to lead the struggle for independence. For a critical analysis, see Bakirathi Mani and Latha Varadarajan, "The Largest Gathering of the Global Indian Family': Neoliberalism, Nationalism, and Diaspora at Pravasi Bharatiya Divas," Diaspora: Journal of Transnational Studies I4:I (2005), pp. 45-74. 
Indian diaspora communities, including business people, cultural leaders, and scholars. The 2010 convention was attended by some I,00o individuals, including politicians of Indian origin from Canada, Fiji, Malaysia, Mauritius, Singapore, and South Africa, as well as from Trinidad and Tobago. The convention involved discussions on a range of issues from nanotechnology to Indian expatriates in the Persian Gulf region.

The MOIA also directs a number of other key initiatives. It administers the Overseas Citizenship of India (OCI) scheme, launched in 2006, which in effect extends to people of Indian origin abroad a permanent visa for entry into India. This scheme has been highly successful in fulfilling its primary objective of reconnecting people of Indian heritage to India, with some 400,000 OCI cards reportedly being issued by early $2009 .{ }^{52}$ To that end, the MOIA also set up a "Tracing Your Roots" service in 2008 to aid those in the diaspora who may be interested in their genealogies and in locating their relatives within India. The MOIA runs various schemes for young diaspora Indians such as the "Know India Program," which offers a three-week orientation to people aged $18-26$ and a scholarship program for Ioo diaspora students to attend Indian universities. At present, the MOIA is establishing a "Persons of Indian Origin University" in Bangalore; in 2009 it advertised for bids to set up four more such universities in other Indian cities. ${ }^{53}$

Finally, since 2006, the MOIA has been charged with responsibility for the welfare of non-resident Indians living and working overseas, many of whom are potentially vulnerable to exploitation. In conjunction with Indian overseas missions, the ministry now coordinates the distribution of funds to aid Indians who need emergency medical treatment, temporary accommodation, or air travel back to India. It runs a dedicated help line in the United Arab Emirates for people in distress or those uncertain about their labor rights, and it is seeking to establish Overseas Indian Centers in areas with significant migrant worker populations. Finally, the MOIA has negotiated a series of bilateral memoranda of understanding with other states concerning social security provisions and other migrant labor rights.

52. "Growing Demand among NRIs to Become Overseas Citizens of India," Economic Times, March 24, 2009, at <http://economictimes.indiatimes.com/News/News-By-Industry/Services/Travel/VisaPower/Growing-demand-among-NRIs-to-become-overseas-citizens-of-India/articleshow/4309902. cms>, accessed May 20, 2011.

53. These initiatives are detailed at $<$ http://moia.gov.in/services.aspx?idI $=24 \&$ idp $=24 \&$ mainid $=23>$, accessed May 20, 20II. 
Taken together, these various efforts add up to a concerted drive on the part of India to assert itself not just as an effective protector of its citizens overseas but as the natural guardian of the wider Indian diaspora, whether its members live in Canada, South Africa, Fiji, or Malaysia. There are similarities here to aspects of China's "charm offensive," and indeed it is apparent that similar ends are sought. Like China, India hopes that reaching out to its diaspora will not just give it leverage over the governments of the nations where they now live, but that it might furnish knowledge, skills, and funds for investment that India needs. ${ }^{54}$

When it comes to engaging non-Indians abroad, India's public diplomacy is more diffuse but no less committed. These efforts fall into two main categories: public diplomacy directed at regional and African states, largely concerning India's new foreign aid, development and technical assistance programs, and public diplomacy aimed at global, mainly Western or Westernized, business and social elites.

India has had a limited foreign aid program for more than half a century, directed mainly at Bhutan, Nepal, and Myanmar/Burma. Since 2000, however, this program has quietly been transformed and supplemented by a number of targeted technical assistance initiatives. Dweep Chanana notes that in 2008, India devoted Rs 26.7 billion ( $\$ 627$ million) to its aid efforts consisting of grants, loans, and contributions to international institutions.5 Much of the new money has gone to Africa and Afghanistan. Between 2007-08 and 2009-IO, India more than doubled its African aid. ${ }^{56}$ Afghanistan, on the other hand, has received close to $\$$ I.5 billion from India since the toppling of the Taliban, with another half-billion dollars promised by Prime Minister Manmohan Singh in May 20II. ${ }^{57}$ The aid effort as a whole is divided between bilateral grants, loans, and guarantees designed to further relationships with particular nations and contributions to multilateral institutions

54. In general, see K. S. Rana, "India’s Diaspora Diplomacy," Hague Journal of Diplomacy 4:3 (2009), pp. 36I-72; and on China’s strategy, see Kurlantzick, Charm Offensive, especially pp. 73-8I. For an analysis of the possible effects of Indian diaspora diplomacy, see also Anita Singh, Stephen Harper's India Policy: The Role and Influence of the Indo-Canadian Diaspora, Ph.D. diss., Dalhousie University, 2010.

55. Dweep Chanana, "India as an Emerging Donor," Economic and Political Weekly 44:I2 (March 2I, 2009), p. II.

56. David M. Malone, Does the Elephant Dance? Contemporary Indian Foreign Policy (Oxford: Oxford University Press, 20II), pp. 88-89.

57. "India Not Like U.S.: Manmohan," The Hindu, May I2, 20II, at <http://www.thehindu.com/ news/national/article20II599.ece?homepage=true>, accessed May 20, 20II. 
with the objective of building India's influence within forums such as the International Monetary Fund.

In Africa, India's explicit objective is to build soft power that can be leveraged for political and economic advantage, partly to help it gain access to raw materials to fuel Indias economic growth..$^{58}$ To that end, India has not just donated funds but has established high-profile high-technology assistance programs. The most prominent is the Pan-African e-Network, a collaborative enterprise with the African Union (AU) inaugurated in 2009 that is designed to build the telecommunications infrastructure needed to support both "tele-education" and "tele-medicine." Costing India over Rs 5.4 billion (\$II5 million), the e-Network will link African universities and hospitals to their Indian counterparts, enabling African students to study for degrees taught by Indian faculty and allowing Africans to have online medical consultations with Indian doctors. More broadly, the e-Network is intended to form the foundation of other kinds of Internet-based cooperation within African states, within the AU, and between the AU and India.99

Alongside these flagship "South-South" initiatives, India's new public diplomacy also targets the Northern rich. It has put concerted efforts into wooing Western business elites, establishing a chain of business councils and chambers of commerce either to build links with the leaders of firms in North America, Europe, Asia, and Oceania, or to revitalize existing organizations. ${ }^{60}$ While the primary aim of these bodies is to foster trade and investment, they also serve as a means of promoting India's image abroad and lobbying for political influence in foreign capitals. The U.S.-India Business Council, for example, collaborated closely with groups such as the U.S. India Political Action Committee (USINPAC, founded in 2002) and the U.S.-India Friendship Council to promote the 2005 U.S.-India Nuclear Agreement to American lawmakers and the wider public. ${ }^{61}$ Elsewhere the political effect of these groups has arguably been less dramatic, but the intention to use such business groups for wider aims has been signaled. The U.K.-India Business

58. Sanusha Naidu, "India’s Growing African Strategy," Review of African Political Economy 35:115 (2008), pp. II6-28.

59. Pan-African e-Network, "Project Launched," at <http://www.panafricanenetwork.com/>, accessed May 20, 20II.

6o. For example, see the Sweden-India Business Council (2003) or the Malaysia-India Business Council (2008). India's Ministry of Commerce records 74 such bilateral bodies (see the list online at <http://commerce.nic.in/aboutus/Bi_Chambers\%2O_Trade.pdf?id=I5>, accessed May 20, 20II).

6I. Subrata Ghoshroy, "The U.S.-India Nuclear Deal: Triumph of the Business Lobby," The Audit of Conventional Wisdom, MIT Center for International Studies, September 20IO, at <http://web.mit. edu/stgs/pdfs/Audit_09_I4_Ghoshroy.pdf>, accessed May 20, 20II. 
Council, for instance, commissions and publishes research on a wide variety of issues and runs its own parliamentary affairs unit dedicated to briefing British members of Parliament on India.

These overtures to the business community have been paralleled by a concerted attempt to shape Western public opinion more generally, using major set-piece exhibitions and targeted "nation-branding." India created a stir at the 2006 Davos summit with its India Everywhere campaign, with pashmina shawls, Bollywood songs, and promotional materials for its high-tech industries being distributed to attendees. It followed this up with India@60 in 2007, involving events in India, the U.S., and Europe, along with coverage in a series of prestigious publications including special issues of Forbes magazine. Since then, India has promoted itself at a series of international events, including a 4,000-square-meter exhibition at the 20I0 Shanghai World Expo advertising its concern for renewable energy as well as more traditional arts and crafts. In 2007, it also launched the Incredible India! campaign, viewed in the public relations world as one of the most easily recognizable efforts at "nation-branding." ${ }^{62}$

Finally, alongside these high-profile initiatives to influence elite opinion, India has lately begun to explore the possibilities of Internet and especially Web 2.0 technologies, particularly online social networking. The MEA's creation of a Twitter account and a Facebook page, noted above, are only the most obvious examples of this shift. Marked efforts have gone into revamping Indian government websites in the past few years. In tacit acknowledgement that it may be the first contact that many will have with India's government, the MOIA's website is noticeably more sophisticated and user-friendly than those of other departments, including the MEA's and the ICCR's. So too are the sites of Indian missions overseas, especially in Western states, and of the various business councils dedicated to promoting bilateral trade and investment. ${ }^{63}$

\section{EFFECTS AND EFFECTIVENESS}

India, conscious of its underused soft power assets, its image problem in the "near abroad," various Chinese efforts, and the opportunities that new social media may offer, has made a significant effort to reform its public diplomacy. It remains to be seen, however, whether this impetus pays the dividend India

62. See Amitabh Kant, Branding India: An Incredible Story (New Delhi: HarperCollins India, 2007).

63. See, for example, the website of the Washington embassy, at <www.indianembassy.org $>$, or the Indian High Commission in Ottawa, at <http://www.hciottawa.ca/>, both accessed May 20, 201 I. 
expects. Soft power is notoriously difficult to translate into clear diplomatic advantage. For all the appeal of Bollywood, biryani, and Bangalore to overseas Indians and foreigners, these assets, and India's renewed commitment to public diplomacy, have done little to shift international public opinion of India's foreign policy. Survey evidence suggests that foreign opinion about India is mixed and-perhaps more important—has not changed significantly even as the nation has emerged as a major global actor.

In 2006, for example, the Chicago Council on World Affairs found that respondents polled in Australia, China, South Korea, and the U.S. were divided on whether India's rise was a welcome development for the world. Perhaps more important, only in Australia did a majority (64\%) say that India could be trusted to play a positive role in international affairs. Americans and South Koreans also expressed serious doubts about whether a militarily more powerful India would be a positive development, with $69 \%$ of Americans and $71 \%$ of South Koreans disagreeing with the proposition. ${ }^{64}$

This ambivalence toward India is borne out too in successive polls commissioned for the BBC World Service in 2006 and 20II. The first surveyed almost 40,000 people in 33 countries. In 22 of these countries, a majority of respondents indicated mainly positive views of India, and in six, they were mainly negative. These results were comparable to those garnered by China, which was viewed positively by a majority of respondents in 20 countries and negatively in Io, but fell far short of Japan's scores (3I positive and two negative). Moreover, only in Afghanistan (59\%) and Iran (71\%) did an absolute majority of respondents express positive views of India. In China and the U.S., opinion was much more evenly split, with positive responses outweighing negatives by margins of less than $10 \%$ (39\% to $32 \%$ for China and $39 \%$ to $33 \%$ for the U.S.). ${ }^{65}$ In the 2010 poll, conducted with a smaller sample of 29 ,000 people in 28 states, India's results were largely unchanged. While $36 \%$ of all respondents expressed positive views of India, 30\% were still negative. By contrast, $40 \%$ expressed positive views of China, $53 \%$ of Japan, and $46 \%$ of the U.S. ${ }^{66}$

64. Chicago Council of World Affairs Global Survey 2006, "The United States and the Rise of China and India," at <http://www.thechicagocouncil.org/UserFiles/File/POS_Topline\%2oReports/ POS\%202006/2006\%20Full\%20POS\%20Report.pdf>, accessed May 20, 20 II.

65. GlobeScan, "Global Poll" (2006), at <http://www.globescan.com/news_archives/bbco6-3/ index.html>, accessed May 20, 201 I.

66. Ibid. (20IO), at <http://www.globescan.com/news_archives/bbc20Io_countries/>, accessed May 20, 20II. 
India's "nation-brand," in other words, is not as well regarded as it might first appear. There is some evidence that India is better regarded among global elites, especially in the West, than it is among the general population. India scores highly, for example, as a tourist destination among those who prize cultural heritage and history ${ }^{67}$ but whether these positive feelings among the Western rich will trickle down to the rest remains uncertain. Moreover, even among such elites, opinion about India is mixed. It continues to rank poorly on Transparency International's Corruption Perception Index, which measures the views of business people about the reputations of countries. In 2009, India ranked 84th out of 180 states in the survey, five points below China and five above Rwanda; in 20I0, India ranked 87 th out of 178 , nine points behind China and on a par with Albania and Liberia. ${ }^{68}$

Clearly, public diplomacy alone cannot address this poor image, which is the result of matters far beyond the control of the ICCR or the MEA. But this does not mean that public diplomacy has no role to play. There is some patchy evidence that targeted public diplomacy by India and its diaspora that tries to influence the views of specific groups, rather than working to shift public opinion as a whole, has produced payoffs. The successful Indian effort to persuade American legislators to support the controversial U.S.-India nuclear deal of 2005 is a case in point: Indian diplomats and lobby groups like USINPAC transformed a skeptical Congress into an enthusiastic supporter of India's rise. ${ }^{69}$ There is also some evidence to suggest that Indian public diplomacy, combined with considerable and well-conceived development aid, has also had a positive effect in Afghanistan, though it is hard to establish how much pro-Indian views reflect negative Afghan perceptions of Pakistani influence. One recent $\mathrm{ABC}$ News poll found that $74 \%$ of Afghan respondents had a favorable view of India and only $2 \mathrm{I} \%$ an unfavorable view, replicating the findings of $\mathrm{BBC}$ surveys. ${ }^{70}$

67. The FutureBrand public relations agency's "Country Brand Index" ranked India the fifth best brand in the Asia-Pacific region in 2009, after Australia, New Zealand, Japan, and Singapore. India was ranked second in the world for "authenticity," second for "history," and third for "art and culture" (at <http://www.futurebrand.com/think/reports-studies/cbi/2009/rankings/>, accessed May 20, 20II).

68. Transparency International, "Corruption Perception Index 2009" and "Corruption Perception Index 20I0," at <http://www.transparency.org/policy_research/surveys_indices/cpi/2009/cpi_2009_ table> and <http://www.transparency.org/policy_research/surveys_indices/cpi/20Io/results>, both accessed May 20, 20II.

69. Jason A. Kirk, "Indian-Americans and the U.S.-India Nuclear Agreement: Consolidation of an Ethnic Lobby," Foreign Policy Analysis 4 (2008), pp. 275-300.

70. Gary Langer, "Frustration with War, Problems in Daily Life Send Afghans' Support for U.S. Efforts Tumbling," ABC News, Polling Unit, February 9, 2009, at <http://abcnews.go.com/ PollingUnit/story?id $=6787686>$, accessed May 20, 20II. When it came to Pakistan, $8 \%$ had a favorable view and $9 \mathrm{I} \%$ an unfavorable one. 
Taken together, this evidence suggests that the Indian foreign policy-making elite's faith in public diplomacy is not wholly unfounded, despite data indicating a lack of movement in foreign public opinion about India in general. Targeted public diplomacy campaigns, conducted in the right circumstances, do seem to pay some dividends if properly conceived and implemented. In that light, well-crafted public diplomacy may prove a good investment.

\section{CONCLUSION}

Since the mid-200os, India has reformed its public diplomacy, reinvesting in traditional modes of building soft power, such as the cultural exchanges organized by the ICCR, and utilizing new methods, including the use of new social media. In part, these efforts are a response to a wider "struggle for soft power" in Asia, stimulated by major investments by the PRC. In part too, they are extensions of India's long-standing concern with public diplomacy, which stretches back into the Nehru era. Lastly, these initiatives have been stimulated by a growing interest among India's foreign policy elite in the possibilities presented by the Internet and especially by Web 2.o.

While there is some evidence to suggest that public diplomacy often struggles to build soft power in the ways that states might wish, this article has suggested that there are some reasons to think that India's efforts in this area might bear some fruit. Views of India's national "brand" have improvedalbeit marginally - over the past few years and patient public and traditional diplomacy can be credited for some of this improvement. ${ }^{71}$ At the same time, as Shashi Tharoor observes, India's elite has become more "conscious" of its present and latent soft power and the potential it might hold for transforming India's international relations. ${ }^{72}$ The key challenge for foreign policy-makers, Tharoor rightly notes, will be how to keep adapting its new and traditional public diplomacy to best manage India's reputation as its politics and society are subjected to greater scrutiny in response to its global "rise."

7I. See especially, Kirk, "Indian-Americans and the U.S.-India Nuclear Agreement."

72. Shashi Tharoor, Pax Indica: India and the World in the 2Ist Century (New Delhi: Allen Lane, 20I2), p. 287. 